\title{
Evaluation of tomato fruit quality response to water and nitrogen management under alternate partial root-zone irrigation
}

\author{
Yang Hui ${ }^{1,2}$, Cao Hongxia ${ }^{1 *}$, Hao Xinmei ${ }^{2}$, Guo Lijie ${ }^{1}$, Li Hongzheng ${ }^{1}$, Wu Xuanyi ${ }^{1}$ \\ (1. Key Laboratory of Agricultural Soil and Water Engineering in Arid and Semiarid Areas of Ministry of Education, \\ Northwest A\&F University, Yangling, Shaanxi 712100, China; \\ 2. Center for Agricultural Water Research in China, China Agricultural University, Beijing 100083, China)
}

\begin{abstract}
A pot experiment was conducted to investigate the effects of different water and nitrogen supply amounts on the comprehensive assessment of tomato fruit quality and root growth parameters under alternate partial root-zone irrigation. Three upper irrigation limitations (i.e. 70\% (W1), 80\% (W2) and 90\% (W3) of field capacity, respectively) and three $\mathrm{N}$-fertilizer levels (i.e. $0.18(\mathrm{~N} 1), 0.30(\mathrm{~N} 2)$ and $0.42(\mathrm{~N} 3) \mathrm{g} / \mathrm{kg}$ soil, respectively) were arranged with a randomized complete block design, and alternate partial root-zone irrigation method was applied. Results showed that fruit yields under deficit irrigation (W1 and W2) were decreased by $6.9 \%$ and $2.0 \%$ respectively compared with W3 under N1 level. Yields of tomato under W1N1 and W1N2 combinations were also reduced by $10.3 \%$ and $7.2 \%$, respectively compared with W1N3 combination. Root dry weight, root length, root surface area and root volume were all increased in W1N2 treatment. According to two-way ANOVA, the root parameters except root dry weight, were extremely sensitive to water, nitrogen and the cross effect of the two factors. TSS (total soluble solids), SS (soluble sugars) and OA (organic acid) in the fruits increased with the decrease in irrigation water, $\mathrm{OA}$ and $\mathrm{NC}$ reduced with decreasing amount of nitrogen. Moreover, within an appropriate range, as more irrigation water and nitrogen were applied, the higher VC (vitamin C) and lycopene contents were identified in the fruits. Eventually, the combinational evaluation method (i.e. entropy method and gray relational analysis) showed that W2N2 ranked highest in comprehensive fruit quality. Therefore, considering the tradeoff between fruit comprehensive quality and yields, upper irrigation limitation of $80 \% \theta_{f}$ and $\mathrm{N}$-fertilizer of $0.30 \mathrm{~g} / \mathrm{kg}$ soil with alternate partial root-zone irrigation was the optimal cultivation strategy for the greenhouse tomato in autumn-winter season in northwest China.
\end{abstract}

Keywords: greenhouse tomato, alternate partial root-zone irrigation, water and nitrogen, root growth, comprehensive fruit quality

DOI: $10.25165 / \mathrm{j} . \mathrm{ijabe} .20171005 .2622$

Citation: Yang H, Cao H X, Hao X M, Guo L J, Li H Z, Wu X Y. Evaluation of tomato fruit quality response to water and nitrogen management under alternate partial root-zone irrigation. Int J Agric \& Biol Eng, 2017; 10(5): 85-94.

\section{Introduction}

Alternate partial root-zone irrigation (APRI) has caught considerable attention as a water-saving irrigation method in recent two decades. APRI means that halves

Received date: 2016-06-05 Accepted date: 2017-05-14 Biographies: Yang Hui, PhD candidate, research interests: water saving irrigation theory and technology, Email: yh2438130@ 163.com; Hao Xinmei, PhD, Associate Professor, research interests: modeling water flow and solute transport in soils under different irrigation, Email: haox@cau.edu.cn; Guo Lijie, PhD candidate, research interests: water saving irrigation theory and technology, Email: gljsxsky@163.com; Li Hongzheng, MS, research interests: water saving irrigation theory and technology, of the root zone are alternately irrigated or left dry during consecutive irrigations ${ }^{[1,2]}$. It has been tested and used in some fruit crops, i.e. peach $^{[3]}$, pear ${ }^{[1]}$, grapevine ${ }^{[4]}$ and tomato $^{[5,6]}$. Previous studies indicated that APRI could significantly reduce transpiration rate while maintaining

Email: leehongzheng@163.com; Wu Xuanyi, Master, research interests: water saving irrigation theory and technology, Email: wxy2016@nwafu.edu.cn.

*Corresponding author: Cao Hongxia, $\mathrm{PhD}$, Associate Professor, research interests: water saving irrigation theory and technology. College of Water Resources and Architectural Engineering, Northwest A\&F University, Weihui Road 23, Yangling, 712100, China. Tel: +86-29-87082902; Fax: +86-29-87081069. Email: chx662002@163.com. 
higher photosynthesis rate ${ }^{[7,8]}$. The mechanism of APRI for reducing transpiration was proposed as that, roots in the drying side could produce abscisic acid (ABA), which might lead to the closure of leaf stomata and therefore reduce the water loss through transpiration, while the wetting side has plentiful supply of water to sustain plant growth $^{[9]}$. The partial root-zone drying (PRD) experiments on tomato showed significant positive results in terms of increasing water use efficiency and fruit quality $^{[6]}$. Compared with conventional furrow irrigation (CFI), alternate furrow irrigation (AFI) maintained same photosynthetic rate $(\mathrm{Pn})$ but with a decreased transpiration rate in grape, meanwhile, AFI increased Vitamin $\mathrm{C}$ and decreased titrated acidity of berry $^{[10]}$. Sun et al. ${ }^{[11]}$ indicated that PRD increased fruit juice concentrations of total soluble solid, glucose, fructose and malic acid. Wei et al. ${ }^{[12]}$ used carbon isotope discrimination to show that APRI increased water use efficiency of tomato at leaf and yield scales.

Both irrigation and nitrogen are important factors for tomato growth, fruit quality and yield ${ }^{[13-16]}$. Although certain degree of irrigation deficit reduced tomato yield, the fruit quality was improved to some extent ${ }^{[17-20]}$. N fertilizer is also important to tomato yield and fruit quality, and has a positive effect on yield and quality if the amount is suitable. Accompanying with the positive relationships between tomato yield and seasonal water applied, proper deficit irrigation improved the total soluble solids, soluble sugars, organic acid and Vitamin C in tomato fruits ${ }^{[15,16,20]}$ as well as water use efficiency ${ }^{[13]}$. It had been proved that the tomato relative yield decreased linearly with the decline of relative seasonal evapotranspiration (ET), mainly in fruit development and ripening stage, while the relative fruit quality parameters increased with the decline of relative seasonal ET, mostly because of the increment by ET deficit in fruit ripening stage $^{[21]}$. Water stress improved dry matter content of the fruit and Brix degree of tomato ${ }^{[22]}$. Increasing $\mathrm{N}$-fertilizer also increased fruit total sugars and organic acid as well as the water productivity ${ }^{[15]}$. However, excessive nitrogen supply may also cause $\mathrm{NO}_{3}-\mathrm{N}$ leaching and affect nitrate content (NC) in tomato fruits $^{[23-25]}$. Therefore, it is obvious that an optimal use of water and nitrogen is critical in achieving high yield and quality as well as water/nitrogen use efficiency of tomato.

Yang et al. ${ }^{[2]}$ reported that alternate drip irrigation reduced mean root dry mass and root hydraulic conductance $(\mathrm{Kr})$ in young apple tree, while Kang et al. ${ }^{[1]}$ indicated that partial root-zone drying significantly enhanced $\mathrm{Kr}$ and the roots had a greater water uptake capacity than CFI in pear tree. However, more details of effects of alternate partial irrigation on root length, root surface area, root volume of tomato under different water and nitrogen supply should be further investigated.

Tomato fruit quality includes different individual quality attributes ${ }^{[26]}$. Generally, the fruit quality is classified as external (size, shape and color), taste (TSS, sugar and organic acid), nutritional (lycopene and vitamin C) and healthful (nitrate content) qualities ${ }^{[27]}$ and each single quality parameter has different importance ratings ${ }^{[19]}$. Therefore, it is crucial to propose a method to calculate the weight of each attribute and determine the comprehensive quality. Among the evaluation methods, entropy method ${ }^{[28]}$ and gray relational analysis (GRA) are two important approaches ${ }^{[16]}$. The entropy method, effectively adopted for determination of weight of the evaluating indicators, is an objective and powerful weight evaluation process ${ }^{[28,29]}$. GRA is a useful tool for solving the complicated interrelationship among the designated multiple performance characteristics ${ }^{[16,30]}$.

There are many studies about tomato yield, water use efficiency and fruit quality responses to alternate partial root-zone irrigation and deficit irrigation. But unfortunately, few studies were done on the effects of different amounts of irrigation water and nitrogen applications under alternate partial root-zone irrigation on the comprehensive assessment of fruit quality and root parameters. Our study is aimed to: (1) explore responses of tomato yield, root parameters and comprehensive fruit quality to different water and nitrogen supply under alternate partial root-zone irrigation; (2) find an effective method to assess the comprehensive fruit quality and establish a suitable water and nitrogen combination strategy for greenhouse tomato in northwest China. 


\section{Materials and methods}

\subsection{Experimental site and materials}

The pot experiment was conducted in a greenhouse at the Key Laboratory of Agricultural Soil and Water Engineering in Arid and Semiarid Area of Ministry of Education in Northwest A\&F University in Yangling, Shaanxi China (latitude $34^{\circ} 18^{\prime} \mathrm{N}$, longitude $108^{\circ} 24^{\prime} \mathrm{E}$, $521 \mathrm{~m}$ altitude) under natural light condition. A local leading variety of fresh tomato, Jinpeng 11, was transplanted on August 11, 2013 and uprooted on November 16, 2013. The experimental site has a semi-humid continental climate with total precipitation of $121.3 \mathrm{~mm}$, mean temperature of $17.3^{\circ} \mathrm{C}$ and mean relative humidity of $71.3 \%$ during the experimental period. Soil in the pot was heavy loam, which was transported from the $20 \mathrm{~cm}$ top layer of a field near the experimental station. Soil pH was 7.8 , field capacity $25.5 \%$, organic matter content $6.18 \mathrm{~g} / \mathrm{kg}$, total $\mathrm{N}$ content $0.81 \mathrm{~g} / \mathrm{kg}$, available $\mathrm{N}$ content $10.93 \mathrm{mg} / \mathrm{kg}$, total $\mathrm{P}$ content $0.42 \mathrm{~g} / \mathrm{kg}$, available $\mathrm{P}$ content $4.18 \mathrm{mg} / \mathrm{kg}$, total $\mathrm{K}$ content $13.8 \mathrm{~g} / \mathrm{kg}$, available $\mathrm{K}$ content $102.3 \mathrm{mg} / \mathrm{kg}$.

\subsection{Experimental design}

The experimental design was a randomized complete block design with nine replications. There were 9 combinations of three irrigation water levels and three nitrogen levels under APRI (Table 1). The irrigation water levels comprised three irrigation upper limitations $\left(\mathrm{W} 1,70 \% \theta_{f} ; \mathrm{W} 2,80 \% \theta_{f} ; \mathrm{W} 3,90 \% \theta_{f}\right), \theta_{f}$ is the field capacity, and three nitrogen treatments included $0.18 \mathrm{~N}$ $\mathrm{g} / \mathrm{kg}(\mathrm{N} 1), 0.30 \mathrm{~N} \mathrm{~g} / \mathrm{kg}$ (N2) and $0.42 \mathrm{~N} \mathrm{~g} / \mathrm{kg}$ (N3) (Table 1). Tomato seedlings at 3-4 true leaves stage were transplanted with one plant to each pot at 30 DAT after sowing. For a better establishment, the tomato plant in each pot was irrigated with $4.6 \mathrm{~L}$ water to field capacity on the day of transplanting. Alternate partial root-zone drying started at $7 \mathrm{~d}$ after transplanting. At 20-30 d after transplanting, the plants stems were staked with plastic string and the flowers were manually pollinated. Other management stages such as pest control and pruning branch were same with local practices. The whole growing season was divided into three stages:

Stage I: vegetative stage (transplant to first fruit set);
Stage II: flowering and fruit development stage (first fruit set to first fruit maturity);

Stage III: fruit ripening stage (first fruit maturity to all fruits harvested).

Table 1 Nitrogen amount and irrigation upper limitation in growth period of tomato

\begin{tabular}{ccccc}
\hline $\begin{array}{c}\text { Nitrogen } \\
\text { treatment }\end{array}$ & $\begin{array}{c}\text { Nitrogen level } \\
/ \mathrm{g} \cdot(\mathrm{kg} \text { soil })\end{array}$ & $\begin{array}{c}\text { Total urea amount } \\
\text { /g per plant }\end{array}$ & $\begin{array}{c}\text { Water } \\
\text { treatment }\end{array}$ & $\begin{array}{c}\text { Upper limitation } \\
\text { of irrigation }\end{array}$ \\
\hline $\mathrm{N} 1$ & 0.18 & 7.043 & $\mathrm{~W} 1$ & $70 \% \theta_{f}$ \\
$\mathrm{~N} 2$ & 0.30 & 11.739 & $\mathrm{~W} 2$ & $80 \% \theta_{f}$ \\
$\mathrm{~N} 3$ & 0.42 & 16.435 & $\mathrm{~W} 3$ & $90 \% \theta_{f}$ \\
\hline
\end{tabular}

Note: $\theta_{f}$ means field capacity.

Seven days after transplanting, the tomato plant was irrigated every three days based on the weighing method, and there was no watering on rainy days in order to prevent the development of gray mold. All the treatments were irrigated to respective upper irrigation limitations set up for each irrigation water level (Table 2). Water was applied using measuring glass through the irrigation tube (Figure 1).

Table 2 Irrigation amount $(\mathrm{mm})$ and times of each treatment under alternate partial root-zone irrigation

\begin{tabular}{cccccc}
\hline \multicolumn{2}{c}{ Treatment } & Stage I & Stage II & Stage III & Whole season \\
\hline T1 & W1N1 & $3.692(3)^{\mathrm{a}}$ & $9.929(12)$ & $6.070(9)$ & $24.291(25)^{\mathrm{b}}$ \\
T2 & W1N2 & $4.638(3)$ & $10.686(12)$ & $6.143(9)$ & $26.067(25)$ \\
T3 & W1N3 & $3.659(3)$ & $9.281(12)$ & $6.008(9)$ & $23.548(25)$ \\
T4 & W2N1 & $4.532(3)$ & $10.666(12)$ & $6.217(9)$ & $26.015(25)$ \\
T5 & W2N2 & $7.163(3)$ & $11.239(12)$ & $6.429(9)$ & $29.431(25)$ \\
T6 & W2N3 & $3.567(3)$ & $11.195(12)$ & $6.139(9)$ & $25.501(25)$ \\
T7 & W3N1 & $5.716(3)$ & $12.769(12)$ & $6.466(9)$ & $29.551(25)$ \\
T8 & W3N2 & $6.306(3)$ & $11.476(12)$ & $6.153(9)$ & $28.535(25)$ \\
T9 & W3N3 & $5.592(3)$ & $12.061(12)$ & $6.270(9)$ & $28.523(25)$ \\
\hline
\end{tabular}

Note: ${ }^{a}$ Numbers in the brackets represent irrigation times with irrigation interval of $3 \mathrm{~d}$ (except rainy days) for the respective growth stage; ${ }^{\mathrm{b}}$ Irrigation amount and times of the whole season include water applied on the day of transplanting.

Tomatoes were transplanted to the experimental pots (30 $\mathrm{cm}$ in diameter at the top edge, $25 \mathrm{~cm}$ in diameter at the bottom, $30 \mathrm{~cm}$ high) (Figure 1). Each pot was filled with $18 \mathrm{~kg}$ soil with a mean bulk density of $1.3 \mathrm{~kg} / \mathrm{m}^{3}$ and vertically installed two PVC tubes $(2.5 \mathrm{~cm}$ in diameter and $30 \mathrm{~cm}$ in depth) at $5 \mathrm{~cm}$ from the bottom of the pot for irrigation. Each tube was drilled to have three rows of round holes longitudinal and was twined with two layers of mesh (1 $\mathrm{mm}$ in diameter). There were six holes punched at the bottom of the pot and paved with silver sand to provide better aeration. Soil surface was covered with $1 \mathrm{~cm}$ thick vermiculite to prevent soil 
surface hardening and evaporation. Under the alternate partial root-zone irrigation, each experimental pot was evenly divided into two parts with a $24 \mathrm{~cm}$ high plastic film to prevent lateral water flow from either side of the root. The plastic film with a V-shaped notch was firmly fixed in the middle of the pot with double sided adhesive tape and each side was installed with one irrigation tube.

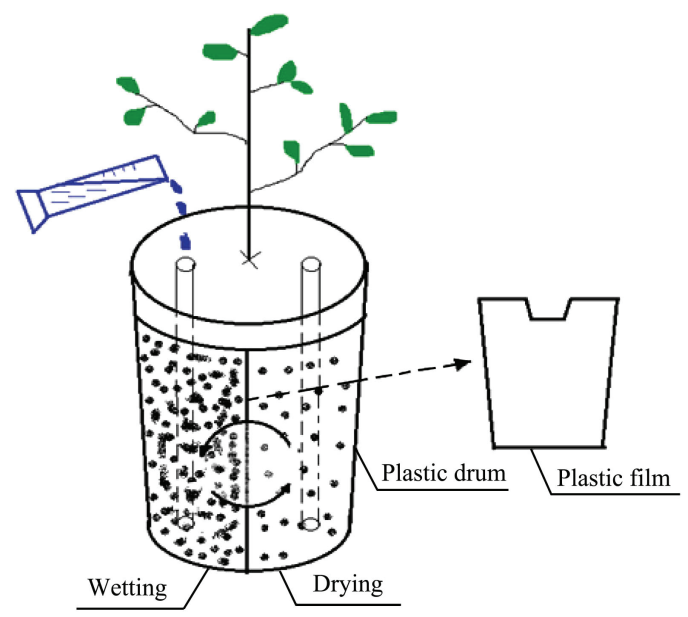

Figure 1 Layout of alternate partial root-zone drying in the pot experiment

$\mathrm{N}, \mathrm{P}, \mathrm{K}$ were supplied as urea (46\% $\mathrm{N}$ included), calcium superphosphate $\left(\begin{array}{llll}15 \% & \mathrm{P}_{2} \mathrm{O}_{5} & \text { included }\end{array}\right)$ and potassium sulfate $\left(50 \% \quad \mathrm{~K}_{2} \mathrm{O}\right.$ included) respectively. Organic fertilizer was applied in rotten chicken manure form. Except for urea amount, other fertilizers were the same for all the treatments with $\mathrm{P}_{2} \mathrm{O}_{5} 0.264 \mathrm{~g} / \mathrm{kg}$ soil, $\mathrm{K}_{2} \mathrm{O} 0.432 \mathrm{~g} / \mathrm{kg}$ soil and organic fertilizer $30 \mathrm{~g} / \mathrm{kg}$ soil. Calcium superphosphate and rotten chicken manure were applied entirely as starter fertilizers. One third of urea and potassium sulfate were applied as starter fertilizers, the remaining were applied evenly on each side of the root with irrigation water in the first and second spike fruit enlargement stage respectively.

\subsection{Measurements}

\subsubsection{Yield, water and nitrogen use}

Tomato fruits were harvested on $76 \mathrm{~d}, 83 \mathrm{~d}, 90 \mathrm{~d}$ after transplanting (DAT), and the fresh weight of fruits per plant was recorded with electronic balance on the harvest day.

Irrigation water use efficiency (IWUE, $\mathrm{kg} / \mathrm{m}^{3}$ ) is calculated as:

$$
I W U E=\frac{Y}{I}
$$

where, $Y$ is fruit yield per plant $(\mathrm{g}) ; I$ is irrigation amount in whole season per plant (L).

Partial factor productivity of nitrogen (PNP, $\mathrm{kg} / \mathrm{kg}$ ) is calculated by the following equation:

$$
P N P=\frac{Y}{N}
$$

where, $N$ is the total $\mathrm{N}$ amount in whole season for per plant $(\mathrm{g})$.

\subsubsection{Root growth parameters}

After harvesting all the red ripen fruits, roots and shoots of three tomato plants were collected separately in each treatment in a randomized manner. The roots were flushed with clean water and then scanned with a root scanner (EPSON Perfection V700, Japan). Root length, root surface area and root volume were obtained through image analysis software (WinRHIZO Pro, Canada), plant materials were firstly dried at $105^{\circ} \mathrm{C}$ for $30 \mathrm{~min}$, and then dried at $70^{\circ} \mathrm{C}$ to a constant weight.

\subsubsection{Fruit quality parameters}

Nine tomato fruits with similar maturity and without external defects were picked from three plants for the quality parameters measurement in each treatment. The fruits were squeezed to juice in a blender for measuring the contents of total soluble solids (TSS), soluble sugars (SS), organic acids (OA), vitamin $\mathrm{C}(\mathrm{VC})$, lycopene and nitrate content (NC). The average values of the three replicates for each treatment were used for fruit quality parameters.

TSS was measured using the electronic handled refractometer (PR-32, Co., Ltd., Tokyo, Japan). SS was determined with the anthrone colorimetric method ${ }^{[31]}$. OA was titrated with $0.1 \mathrm{~mol} / \mathrm{L} \mathrm{NaOH}$ and figured as equivalents of citric acid expressed as percentage of fresh mass $^{[32]}$. VC was measured with the extractionmolybdate blue spectrophotometric method ${ }^{[33]}$. Lycopene was determined with spectrophotometric method ${ }^{[34]}$. NC was measured with spectrophotometric method ${ }^{[35]}$.

\subsection{Calculating index weight by entropy method}

The entropy method was used to assess tomato quality parameters in this study. Procedure of conducting entropy analysis is as follows ${ }^{[28]}$.

Normalization of fruit quality parameters: The normalized values $p_{i j}$ is expressed as: 


$$
p_{i j}=\frac{x_{i j}}{\sum_{i=1}^{m} x_{i j}}
$$

where, $x_{i j}$ is the $j^{\text {th }}$ quality parameter in the $i^{\text {th }}$ treatment; in this study, $m=9$.

The entropy of $j^{\text {th }}$ quality parameter, $e_{j}$ is defined as:

$$
e_{j}=-k \sum_{i=1}^{m} p_{i j}\left(\ln p_{i j}\right)
$$

where, constant $k$ is related to $m$, and set as $1 / \mathrm{ln}(\mathrm{m})$.

The entropy weight $w_{j}$ is then defined as:

$$
w_{j}=\frac{1-e_{j}}{\sum_{j=1}^{n}\left(1-e_{j}\right)}
$$

where, $n=5$. The smaller value of entropy for a given indicator indicates that this indicator provides more useful information, and correspondingly the weight of this indicator should be higher.

\subsection{Calculating comprehensive quality rank with GRA}

Grey relational analysis (GRA) was used to assess the comprehensive quality of tomato fruits in our study. Each treatment is considered as one of the elements in the gray system. The procedure involves the following steps $^{[36-38]}$.

The original parameters are normalized at the range between 0 and 1.0. $\quad Y_{0}$ is defined as the maximum value of each single quality parameter. Therefore the normalized values, $x_{i j}$ is expressed as:

$$
x_{i j}=\frac{y_{i j}}{y_{o j}}
$$

where, $y_{i j}$ is the $j^{\text {th }}$ quality parameter in the $i^{\text {th }}$ treatment; $y_{o j}$ is the value of ideal treatment.

The gray relational coefficients, $\varepsilon_{i j}$ is calculated as:

$$
\xi_{i j}=\frac{\min _{i} \min _{j}\left|x_{i}^{o}-x_{i j}\right|+\zeta \max _{i} \max _{j}\left|x_{i}^{o}-x_{i j}\right|}{\left|x_{i}^{o}-x_{i j}\right|+\zeta \max _{i} \max _{j}\left|x_{i}^{o}-x_{i j}\right|}
$$

where, $x_{i}^{o}$ is the ideal normalized value for the $i^{\text {th }}$ quality parameter; $\zeta$ is the distinguishing coefficient, $\zeta \in[0,1]$, $\zeta=0.5$ is generally used.

The grey relational grade is defined and calculated as follows:

$$
R_{i}^{*}=\sum_{k=1}^{n} w_{j} \xi_{i}(k)
$$

where, $R_{i}^{*}$ is the gray relational grade for the $i^{\text {th }}$ treatment; and $w_{j}$ is the weighting factor for the $i^{\text {th }}$ quality parameter, which comes from entropy method.

\subsection{Statistical analysis}

The experimental data were analyzed by two-way ANOVA using SPSS software. Differences between means were compared for any significant differences using the Duncan's multiple range tests at significant level of $p<0.05$.

\section{Results}

\subsection{Effects of water and nitrogen management on root growth}

As shown in Table 3, tomato root length ranged from $3417.6 \mathrm{~cm}$ to $5493.8 \mathrm{~cm}$ under APRI. The decline of root dry weight reached $3.7 \%$ for $\mathrm{W} 2 \mathrm{~N} 3$ and $9.3 \%$ for W3N3, respectively compared with W1N3. N2 treatments increased root length under the same water level. Root surface area of W1N1 and W2N1 decreased $30.0 \%$ and $12.2 \%$ in comparison with W3N1. Root volume first increased then decreased with the increasing nitrogen under the same water level. W2N2 treatment had much higher root parameters (root dry weight, root length, root surface area and root volume) than any other treatments under APRI. The two-way ANOVA of water effect, nitrogen effect and cross effect of water and

\begin{tabular}{|c|c|c|c|c|c|c|}
\hline \multicolumn{2}{|c|}{ Treatment } & \multirow{2}{*}{$\begin{array}{l}\begin{array}{l}\text { Root dry } \\
\text { weight/g }\end{array} \\
2.20 \mathrm{bc}\end{array}$} & \multirow{2}{*}{$\begin{array}{c}\begin{array}{c}\text { Root length } \\
\text { /cm }\end{array} \\
3417.6 \mathrm{~d}\end{array}$} & \multirow{2}{*}{$\begin{array}{c}\begin{array}{c}\text { Root surface } \\
\text { area/cm }\end{array} \\
277.6 \mathrm{~g}\end{array}$} & \multirow{2}{*}{$\begin{array}{c}\begin{array}{c}\text { Root volume } \\
/ \mathrm{cm}^{3}\end{array} \\
4.22 \mathrm{e}\end{array}$} & \multirow{2}{*}{$\begin{array}{c}\begin{array}{c}\text { Yield } \\
\text { /g per plant }\end{array} \\
823.7 \mathrm{f}\end{array}$} \\
\hline $\mathrm{T} 1$ & W1N1 & & & & & \\
\hline $\mathrm{T} 2$ & W1N2 & $2.37 b c$ & $3957.2 \mathrm{c}$ & $418.8 \mathrm{e}$ & $6.49 \mathrm{c}$ & $852.3 \mathrm{ef}$ \\
\hline T3 & W1N3 & $2.15 \mathrm{bc}$ & $3839.4 \mathrm{c}$ & $334.1 \mathrm{f}$ & $4.44 \mathrm{e}$ & $918.0 \mathrm{~d}$ \\
\hline $\mathrm{T} 4$ & W2N1 & $2.51 \mathrm{ab}$ & $3928.9 c$ & $348.2 \mathrm{f}$ & $4.88 \mathrm{~d}$ & $867.9 \mathrm{e}$ \\
\hline T5 & W2N2 & $3.11 \mathrm{a}$ & $5493.8 \mathrm{a}$ & $732.9 \mathrm{a}$ & $9.10 \mathrm{a}$ & $1075.2 \mathrm{a}$ \\
\hline T6 & $\mathrm{W} 2 \mathrm{~N} 3$ & $2.07 \mathrm{c}$ & $5253.9 \mathrm{ab}$ & $667.1 \mathrm{~b}$ & $8.23 b$ & $1056.0 \mathrm{ab}$ \\
\hline T7 & W3N1 & $2.35 \mathrm{bc}$ & $3923.4 \mathrm{c}$ & $396.7 \mathrm{e}$ & $4.98 \mathrm{~d}$ & $885.2 \mathrm{de}$ \\
\hline T8 & W3N2 & $2.74 \mathrm{ab}$ & $5085.1 b$ & $589.9 \mathrm{c}$ & $7.94 b$ & $1027.1 \mathrm{~b}$ \\
\hline T9 & W3N3 & $1.95 \mathrm{c}$ & $4000.5 c$ & $553.7 \mathrm{~d}$ & $6.61 \mathrm{c}$ & $955.1 \mathrm{c}$ \\
\hline & W & ns & $* *$ & $* *$ & $* *$ & $* *$ \\
\hline & $\mathrm{N}$ & $* *$ & $* *$ & $* *$ & $* *$ & $* *$ \\
\hline & $\mathrm{W} \times \mathrm{N}$ & ns & $* *$ & $* *$ & $* *$ & $* *$ \\
\hline
\end{tabular}
nitrogen were extremely significant except water effect and cross effect on root dry weight.

Table 3 Root parameters and yield of tomato as affected by water and nitrogen management under alternate partial

root-zone irrigation

Notes: Different letters in each column indicate significant differences according to the Duncan's multiple range tests at $p=0.05$ level. $\mathrm{W}$ : water regime effect; $\mathrm{N}$ : nitrogen regime effect; $\mathrm{W} \times \mathrm{N}$ : water and nitrogen cross effect. * Significant differences for $p<0.05$; ** Significant differences for $p<0.01$; ns: no significance. 


\subsection{Effects of water and nitrogen management on} yield, water and nitrogen use

Tomato yields from $\mathrm{W} 1 \mathrm{~N} 1$ and $\mathrm{W} 1 \mathrm{~N} 2$ were decreased by $10.3 \%$ and $7.2 \%$, respectively compared with W1N3 under APRI. Under the W2 and W3 level, yield was not always increased with the increment of nitrogen, the decline of yield reached $1.8 \%$ for $\mathrm{W} 2 \mathrm{~N} 3$ and $7.0 \%$ for $\mathrm{W} 3 \mathrm{~N} 3$, respectively compared with $\mathrm{W} 2 \mathrm{~N} 2$ and W3N2. Moreover, the decline of yield reached $6.9 \%$ for $\mathrm{W} 1 \mathrm{~N} 1$ and $2.0 \%$ for $\mathrm{W} 2 \mathrm{~N} 1$ under $\mathrm{APRI}$, respectively compared with $\mathrm{W} 3 \mathrm{~N} 1$. Under the N2 and N3 level, the yield first increased then decreased with the increment of water, and W2N2 obtained a maximum yield of $1075.2 \mathrm{~g} /$ plant under APRI.

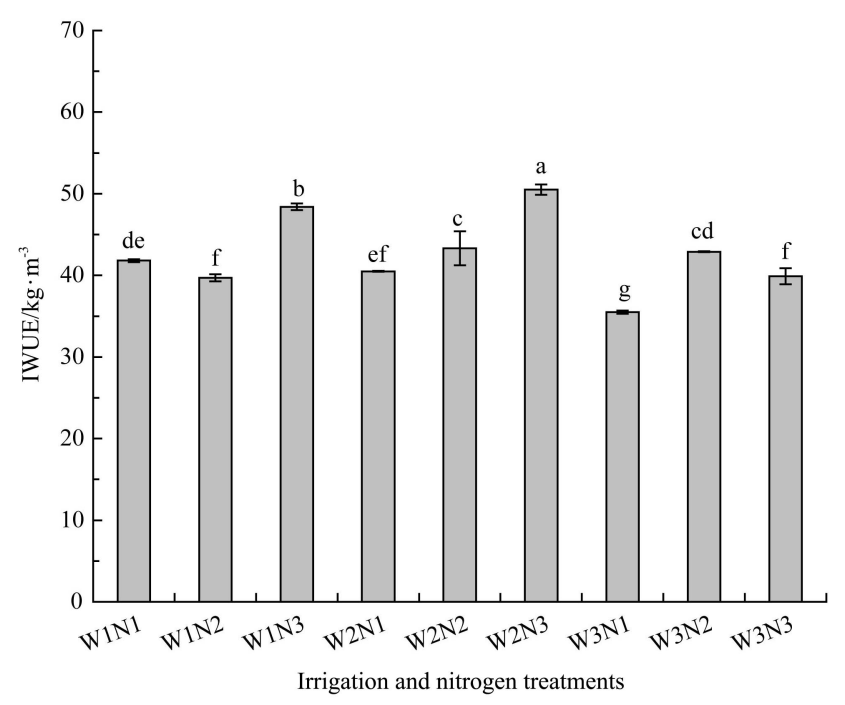

a

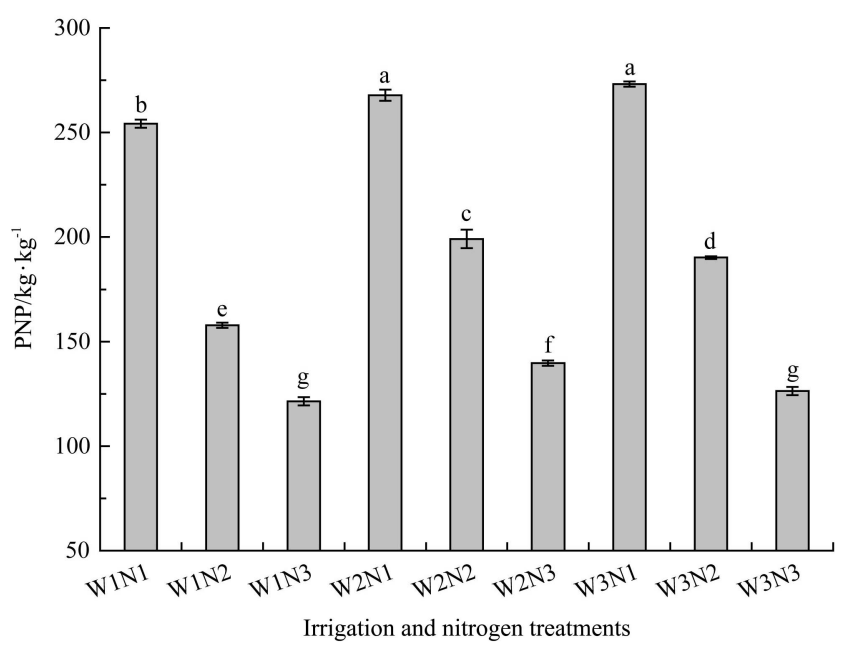

Figure 2 The irrigation water use efficiency (IWUE) and nitrogen partial productivity (PNP) of each treatment under alternate partial root-zone drying. Letters above the error bars were the significant differences according to the Duncan's multiple range test at $p=0.05$ level
Irrigation water use efficiency (IWUE) and nitrogen partial productivity (PNP) reflected the economic yield of the tomato crop produced by unit water consumption and unit nitrogen amount, respectively. The IWUE and PNP of APRI ranged from $35.5 \mathrm{~kg} / \mathrm{m}^{3}$ to $50.5 \mathrm{~kg} / \mathrm{m}^{3}$ and from $121.4 \mathrm{~kg} / \mathrm{kg}$ to $273.3 \mathrm{~kg} / \mathrm{kg}$, respectively. Compared with W2N3, the IWUE were decreased ranging from $4.1 \%$ (T3) to $29.7 \%(\mathrm{~T} 7)$ for different treatments (Figure 2a), respectively. N1 treatments had a much higher PNP than that of any other nitrogen treatments under the same water regime (Figure $2 b$ ). The PNP in W2 treatments were higher than those of W1 and $\mathrm{W} 3$ treatments under the same nitrogen level.

\subsection{Effects of water and nitrogen management on tomato quality}

As shown in Table 4, TSS, Vc, lycopene and SS were initially increasing, but decreased with the increment of nitrogen under the same water levels. However, OA and NC continued to increase. This indicated that N2 treatment performed well in achieving optimal fruit quality parameters of tomato. Under the same nitrogen level, the more stressful the irrigation water, the higher the TSS content identified in the fruits. Within an appropriate range, $\mathrm{Vc}$, lycopene and $\mathrm{NC}$ increased with the increment in water.

Table 4 Tomato quality parameters as affected by water and nitrogen management under alternate partial root-zone irrigation

\begin{tabular}{cccccccc}
\hline Treatment & TSS/\% & $\begin{array}{c}\mathrm{VC} \\
/ \mathrm{mg} \cdot 100 \mathrm{~g}^{-1}\end{array}$ & $\begin{array}{c}\text { Lycopene } \\
/ \mu \mathrm{g} \cdot \mathrm{g}\end{array}$ & $\mathrm{RS} / \%$ & $\mathrm{OA} / \%$ & $\begin{array}{c}\mathrm{NC} \\
/ \mathrm{mg} \cdot \mathrm{kg}\end{array}$ \\
\hline $\mathrm{T} 1$ & $\mathrm{~W} 1 \mathrm{~N} 1$ & $7.87 \mathrm{~b}$ & $15.83 \mathrm{e}$ & $28.55 \mathrm{c}$ & $3.79 \mathrm{bc}$ & $0.59 \mathrm{e}$ & $73.1 \mathrm{bc}$ \\
$\mathrm{T} 2$ & $\mathrm{~W} 1 \mathrm{~N} 2$ & $8.60 \mathrm{a}$ & $22.63 \mathrm{ab}$ & $45.55 \mathrm{ab}$ & $5.92 \mathrm{a}$ & $0.63 \mathrm{de}$ & $81.0 \mathrm{bc}$ \\
$\mathrm{T} 3$ & $\mathrm{~W} 1 \mathrm{~N} 3$ & $8.57 \mathrm{a}$ & $20.80 \mathrm{bc}$ & $28.80 \mathrm{c}$ & $4.24 \mathrm{~b}$ & $0.79 \mathrm{~b}$ & $123.1 \mathrm{a}$ \\
$\mathrm{T} 4$ & $\mathrm{~W} 2 \mathrm{~N} 1$ & $6.60 \mathrm{~d}$ & $18.93 \mathrm{~cd}$ & $35.40 \mathrm{bc}$ & $3.37 \mathrm{bc}$ & $0.71 \mathrm{c}$ & $84.0 \mathrm{bc}$ \\
$\mathrm{T} 5$ & $\mathrm{~W} 2 \mathrm{~N} 2$ & $8.33 \mathrm{a}$ & $23.68 \mathrm{a}$ & $48.40 \mathrm{a}$ & $4.65 \mathrm{ab}$ & $0.86 \mathrm{a}$ & $120.1 \mathrm{a}$ \\
$\mathrm{T} 6$ & $\mathrm{~W} 2 \mathrm{~N} 3$ & $7.94 \mathrm{~b}$ & $21.83 \mathrm{ab}$ & $44.68 \mathrm{ab}$ & $4.19 \mathrm{bc}$ & $0.86 \mathrm{a}$ & $126.7 \mathrm{a}$ \\
$\mathrm{T} 7$ & $\mathrm{~W} 3 \mathrm{~N} 1$ & $5.70 \mathrm{e}$ & $17.45 \mathrm{de}$ & $24.75 \mathrm{c}$ & $2.77 \mathrm{c}$ & $0.42 \mathrm{f}$ & $57.3 \mathrm{c}$ \\
$\mathrm{T} 8$ & $\mathrm{~W} 3 \mathrm{~N} 2$ & $7.27 \mathrm{c}$ & $22.15 \mathrm{ab}$ & $46.95 \mathrm{ab}$ & $4.58 \mathrm{ab}$ & $0.64 \mathrm{de}$ & $105.9 \mathrm{ab}$ \\
$\mathrm{T} 9$ & $\mathrm{~W} 3 \mathrm{~N} 3$ & $7.00 \mathrm{c}$ & $20.77 \mathrm{bc}$ & $25.65 \mathrm{c}$ & $3.99 \mathrm{bc}$ & $0.66 \mathrm{~cd}$ & $123.4 \mathrm{a}$ \\
\hline & $\mathrm{W}$ & $* *$ & $\mathrm{~ns}$ & $\mathrm{~ns}$ & $\mathrm{~ns}$ & $* *$ & $\mathrm{~ns}$ \\
& $\mathrm{~N}$ & $* *$ & $* *$ & $* *$ & $* *$ & $* *$ & $* *$ \\
\multicolumn{2}{c}{$\mathrm{W} \times \mathrm{N}$} & $* *$ & $\mathrm{~ns}$ & $\mathrm{~ns}$ & $\mathrm{~ns}$ & $* *$ & $\mathrm{~ns}$ \\
\hline
\end{tabular}

Notes: TSS: total soluble solids, Vc: vitamin C, SS: soluble sugars, OA: organic acids, NC: nitrate content. Different letters in each column indicate significant differences according to the Duncan's multiple range tests at $p=0.05$ level. W: water regime effect; $\mathrm{N}$ : nitrogen regime effect; $\mathrm{W} \times \mathrm{N}$ : water and nitrogen cross effect. * Significant differences for $p<0.05$; ** Significant differences for $p<0.01$; ns: no significant. 
The decline of SS reached $11.1 \%$ for $\mathrm{W} 2 \mathrm{~N} 1$ and $26.9 \%$ for W3N1, respectively compared with W1N1. The two-way ANOVA showed that effects of water, nitrogen and cross effect of the two factors on TSS and OA were extremely significant, nitrogen effect on $\mathrm{VC}$, lycopene, RS and $\mathrm{NC}$ was also extremely significant.

\subsection{Rankings of comprehensive fruit quality}

The comprehensive quality rankings using GRA and entropy method were showed in Table 5, W2N2 and W1N2 ranked the first and second, respectively. And W3N1 was the last. Consequently, the high irrigation amount and low nitrogen supply were difficult to obtain the better quality under APRI.

Table 5 Rankings of the comprehensive tomato quality with GRA method

\begin{tabular}{cccccccc}
\hline & $X_{1}$ & $X_{2}$ & $X_{3}$ & $X_{4}$ & $X_{5}$ & $R_{i}^{*}$ & The rank of $R_{i}^{*}$ \\
\hline$\xi_{1}$ & 0.801 & 0.467 & 0.463 & 0.494 & 0.482 & 0.541 & 8 \\
$\xi_{2}$ & 0.992 & 0.706 & 0.857 & 0.989 & 0.510 & 0.811 & 2 \\
$\xi_{3}$ & 0.981 & 0.621 & 0.467 & 0.553 & 0.680 & 0.660 & 5 \\
$\xi_{4}$ & 0.601 & 0.553 & 0.569 & 0.450 & 0.585 & 0.552 & 6 \\
$\xi_{5}$ & 0.913 & 0.766 & 1.000 & 0.619 & 0.793 & 0.818 & 1 \\
$\xi_{6}$ & 0.818 & 0.666 & 0.822 & 0.545 & 0.793 & 0.729 & 3 \\
$\xi_{7}$ & 0.511 & 0.508 & 0.420 & 0.399 & 0.389 & 0.446 & 9 \\
$\xi_{8}$ & 0.692 & 0.682 & 0.922 & 0.606 & 0.521 & 0.685 & 4 \\
$\xi_{9}$ & 0.653 & 0.619 & 0.430 & 0.519 & 0.536 & 0.551 & 7 \\
$w_{j}$ & 0.089 & 0.083 & 0.376 & 0.227 & 0.225 & & \\
\hline
\end{tabular}

Notes: $X_{1}$ means TSS, $X_{2}$ means Vc, $X_{3}$ means Lycopene, $X_{4}$ means $\mathrm{SS}, X_{5}$ means $\mathrm{OA} ; \xi_{1}-\xi_{9}$ are the correlation coefficient; $w_{j}$ is the weight of single quality parameter from entropy method; $R_{i}^{*}$ is the weighted correlation.

\section{Discussion}

Many studies had proved that APRI improved the water use efficiency and fertilizer-N use efficiency ${ }^{[39-42]}$. Wang et al. ${ }^{[42]}$ pointed out that APRI had no significant influence on tomato yield with $34.3 \%$ water saved. Tomato is a water and fertilizer demanding crop. Yield decreased with the drop of irrigation water ${ }^{[20,43]}$, however increasing $\mathrm{N}$ rate improved tomato yield ${ }^{[15]}$. The present experiment proved that tomato yield increased initially and then decreased as the levels of irrigation and nitrogen amounts increased under APRI. Adequate lower irrigation water application and higher nitrogen amounts might achieve high IWUE and PNP as suggested by earlier studies ${ }^{[44,45]}$. Thus W2N2 treatment was the suitable strategy for water saving and maximizing yield under APRI.
Tomato root, the major organ of water and nitrogen absorption, was significantly affected by the amounts of irrigation water and nitrogen (Table 3). It had been widely reported that APRI regulated the proportion of photosynthetic product in root and shoot, and optimized the root-shoot ratio by promoting root growth ${ }^{[46,47]}$. This study under APRI showed that increasing the water and nitrogen amounts would initially increase root parameters such as dry weight, length, surface area and volume and then a reduction occurs. This phenomenon proved the conclusion that appropriate irrigation water application and optimized amount of nitrogen applied would result in getting more yield under APRI ${ }^{[48-50]}$.

Previous studies indicated that crop yield under APRI was improved with significant increment of soluble solid content, vitamin C, and soluble protein ${ }^{[10]}$. Deficit irrigation seemed generally, tend to improve TSS and SS in tomato fruits ${ }^{[19]}$, mostly because water stress increased the activities of sucrose synthase and sucrose phosphate synthase, which enlarged the gradient of sucrose concentration between leaves and fruits ${ }^{[51]}$. Water deficit was proved to increase $\mathrm{Vc}$ content in tomato fruits ${ }^{[17,18]}$, but no significant evidence showed that nitrogen could improve Vc. The study indicated that deficit irrigation increased TSS, SS and OA in tomato fruits, and high nitrogen amount improved $\mathrm{OA}$ and $\mathrm{NC}$ in fruits (Table 4). Moreover, within an appropriate range, the more irrigation water and nitrogen were applied, the higher the contents of $\mathrm{Vc}$ and lycopene would be identified in the fruits (Table 4).

Tomato fruit quality was a crucial factor for the determination of irrigation and nitrogen strategy. But the quality was a comprehensive concept and was difficult to be defined. In this study, the entropy method and GRA were used to assess the comprehensive fruit quality of tomato and to determine the optimal water and nitrogen combination management. The results showed that lycopene, SS and OA had a higher weight than other quality parameters (Table 5), suggesting that the taste and nutritional qualities were important assessment criteria for tomato quality. Moreover, W2N2 and W1N2 were ranked first and second, respectively. W3N1 was the last. In this manner, W2N2 was the appropriate water 
and nitrogen combination management for greenhouse tomato under alternate partial root-zone irrigation.

\section{Conclusions}

Appropriate deficit irrigation method and right application of nitrogen could guarantee tomato yield and root growth, and also improved fruit quality. Fruit parameters (TSS, SS, and OA) increased with the decrease in irrigation amount, $\mathrm{N}$-fertilizer had significant influence on $\mathrm{NC}$ and $\mathrm{OA}$. The more nitrogen that was applied resulted in higher contents of $\mathrm{NC}$ and $\mathrm{OA}$ identified in the fruits. High IWUE and PNP were achieved by low irrigation and high nitrogen amounts. Furthermore, the combinational evaluation result showed that W2N2 recorded the best in comprehensive fruit quality. Therefore, deficit irrigation of $80 \% \theta_{f}$ and $\mathrm{N}$-fertilizer of $0.30 \mathrm{~g} / \mathrm{kg}$ soil with alternate partial root-zone irrigation was the best cultivation strategy for the comprehensive fruit quality and yields of greenhouse tomato in northwest China.

\section{Acknowledgements}

We are grateful for the grant support from the National High-Tech 863 Project of China (2013AA103004) and the program of Water Conservancy Science and Technology Plan of shaanxi Province (2014slkj-17).

\section{[References]}

[1] Kang $\mathrm{S} \mathrm{Z}, \mathrm{Hu} X \mathrm{~T}, \mathrm{Du} \mathrm{T} \mathrm{S}$, Zhang $\mathrm{J} \mathrm{H}$, Jerie $\mathrm{P}$. Transpiration coefficient and ratio of transpiration to evapotranspiration of pear tree (Pyrus communis L.) under alternative partial root-zone drying conditions. Hydrol. Process, 2003; 17(6): 1165-1176.

[2] Yang Q L, Zhang F C, Li F S. Effect of different drip irrigation methods and fertilization on growth, physiology and water use of young apple tree. Sci. Hortic, 2011; 129(1): 119-126.

[3] Goldhammer D A, Salinas M, Crisosto C, Day K R, Soler M, Moriana A. Effects of regulated deficit irrigation and partial root zone drying on late harvest peach tree performance. International Peach Symposium, 2001; 592: 343-350.

[4] Du T S, Kang S Z, Zhang J H, Li F S, Yan B Y. Water use efficiency and fruit quality of table grape under alternate partial root-zone drip irrigation. Agric. Water Manage,
2008; 95(6): 659-668.

[5] Wang Y S, Liu F L, Jensen L S, Neergaard A D, Jensen C R. Alternate partial root-zone irrigation improves fertilizer-N use efficiency in tomatoes. Irri. Sci, 2013; 31(4): 589-598.

[6] Casa R, Rouphael Y. Effects of partial root-zone drying irrigation on yield, fruit quality, and water-use efficiency in processing tomato. J. Hortic. Sci. Biotechnol, 2014; 89(4): 389-396.

[7] Kang S Z, Zhang J H. Controlled alternate partial root-zone irrigation: its physiological consequences and impact on water use efficiency. J. Exp. Bot, 2004; 55(407): 2437-2446.

[8] Kirda C, Cetin M, Dasgan Y, Topcu S, Kaman H, Ekici B, Derici M R, Ozguven A I. Yield response of greenhouse grown tomato to partial root drying and conventional deficit irrigation. Agric. Water Manage, 2004; 69(3): 191-201.

[9] Du T S, Kang S Z, Zhang J H, Li F S, Hu X T. Yield and physiological responses of cotton to partial root-zone irrigation in the oasis field of northwest China. Agric. Water Manage, 2006; 84(1): 41-52.

[10] Du T S, Kang S Z, Yan B Y, Zhang J H. Alternate furrow irrigation: a practical way to improve grape quality and water use efficiency in arid Northwest China. J. Integr. Agric, 2013; 12(3): 509-519.

[11] Sun Y, Holm P E, Liu F. Alternate partial root-zone drying irrigation improves fruit quality in tomatoes. Horti. Sci, 2014; 41(4): 185-191.

[12] Wei Z H, Du T S, Zhang J, Xu S J, Cambre P J, Davies W J. Carbon isotope discrimination shows a higher water use efficiency under alternate partial root-zone irrigation of field-grown tomato. Agric. Water Manage, 2016; 165: 33-43.

[13] Mahajan G, Singh K G. Response of greenhouse tomato to irrigation and fertigation. Agric. Water Manage, 2006; 84(1): 202-206.

[14] Sun Y, Hu K L, Fan Z B, Wei Y P, Lin S, Wang J G. Simulating the fate of nitrogen and optimizing water and nitrogen management of greenhouse tomato in North China using the EU-Rotate-N model. Agric. Water Manage, 2013; 128: 72-84.

[15] Kuscu H, Turhan A, Ozmen N, Aydinol P, Demir A O. Optimizing levels of water and nitrogen applied through drip irrigation for yield, quality, and water productivity of processing tomato (Lycopersicon esculentum Mill.). Hortic. Environ. Biotechnol, 2014; 55(2): 103-114.

[16] Wang C X, Gu F, Chen J L, Yang H, Jiang J J, Du TS, et al. Assessing the response of yield and comprehensive fruit quality of tomato grown in greenhouse to deficit irrigation and nitrogen application strategies. Agric. Water Manage, 2015; 161: 9-19. 
[17] Patanè C, Cosentino S L. Effects of soil water deficit on yield and quality of processing tomato under a Mediterranean climate. Agric. Water Manage, 2010; 97(1): 131-138.

[18] Patanè C, Tringali S, Sortino O. Effects of deficit irrigation on biomass, yield, water productivity and fruit quality of processing tomato under semi-arid Mediterranean climate conditions. Sci. Hortic, 2011; 129(4): 590-596.

[19] Wang F, Kang S Z, Du T S, Li F S, Qiu R J. Determination of comprehensive quality index for tomato and its response to different irrigation treatments. Agric. Water Manage, 2011; 98(8): 1228-1238.

[20] Chen J L, Kang S Z, Du T S, Qiu R J, Guo P, Chen R Q. Quantitative response of greenhouse tomato yield and quality to water deficit at different growth stages. Agric. Water Manage, 2013; 129: 152-162.

[21] Chen J L, Kang S Z, Du T S, Guo P, Qiu R J, Chen R Q, et al. Modeling relations of tomato yield and fruit quality with water deficit at different growth stages under greenhouse condition. Agric. Water Manage, 2014; 146: 131-148.

[22] Sirigu A, Mameli M G, Chessa F, Meloni S. Effect of partial root zone drying on growth, yield and fruit quality in greenhouse tomato cultivation. VIII International Symposium on Protected Cultivation in Mild Winter Climate. Advances in Soil and Soilless Cultivation, 2006; 747: 219-226.

[23] Yang S M, Malhi S S, Song J R, Xiong Y C, Yue W Y, Lu L $\mathrm{L}$, et al. Crop yield, nitrogen uptake and nitrate-nitrogen accumulation in soil as affected by 23 annual applications of fertilizer and manure in the rainfed region of Northwestern China. Nutr. Cycl. Agroecosyst, 2006; 76(1): 81-94.

[24] Zotarelli L, Scholberg J M, Dukes M D, Muñoz-Carpena R, Icerman J. Tomato yield, biomass accumulation, root distribution and irrigation water use efficiency on a sandy soil, as affected by nitrogen rate and irrigation scheduling. Agric. Water Manage, 2009; 96(1): 23-34.

[25] Zotarelli L, Dukes M D, Scholberg J M, Muñoz-Carpena R, Icerman J. Tomato nitrogen accumulation and fertilizer use efficiency on a sandy soil, as affected by nitrogen rate and irrigation scheduling. Agric. Water Manage, 2009; 96(8): $1247-1258$.

[26] Du T S, Kang S Z. Efficient water-saving irrigation theory based on the response of water and fruit quality for improving quality of economic crops. J. Hydraul. Eng, 2011; 42(2): 245-252. (in Chinese)

[27] Viskelis P, Jankauskiene J, Bobinaite R. Content of carotenoids and physical properties of tomatoes harvested at different ripening stages. In: Foodbalt-2008, 2008; pp. 166-170.

[28] Zou Z H, Yi Y, Sun J N. Entropy method for determination of weight of evaluating indicators in fuzzy synthetic evaluation for water quality assessment. J. Environ. Sci, 2006; 18(5): 1020-1023.

[29] Wu X, Wang K Y, Niu X L, Hu T T. Construction of comprehensive nutritional quality index for tomato and its response to water and fertilizer supply. Trans. Chin. Soc. Agric. Eng, 2014; 30(7): 119-127. (in Chinese)

[30] Tamrin K F, Nukman Y, Sheikh N A, Harizam M Z. Determination of optimum parameters using grey relational analysis for multi-performance characteristics in $\mathrm{CO}_{2}$ laser joining of dissimilar materials. Opt. Lasers Eng, 2014; 57: $40-47$.

[31] Li H S. The Principle and Technology of Plant Physiology and Biochemistry Experiment. Higher Education Press, Beijing, 2000; pp.195-196. (in Chinese)

[32] AOAC, 1990. Official Methods of Analysis, 15th ed. Association of Official Analytical Chemists, Washington, DC.

[33] AOAC. Vitamin C (Ascorbic Acid) in Vitamin Preparations and Juices: 2,6-Dichloroindophenol Titrimetric Method. Association of Official Analytical Chemists, Washington, DC, 1984; pp.844-845.

[34] Zhang L F, Dong X L. Establishment of a new lycopene determination method. Food and Fermentation Industries, 2001; 27(3): 51-55.

[35] García-Robledo E, Corzo A, Papaspyrou S. A fast and direct spectrophotometric method for the sequential determination of nitrate and nitrite at low concentrations in small volumes. Mar. Chem, 2014; 162: 30-36.

[36] Kang J, Zou Z H. Time prediction model for pipeline leakage based on grey relational analysis. Phys. Proc, 2012; 25: 2019-2024.

[37] Xiao X C, Wang X Q, Fu K Y, Zhao Y J. Grey relational analysis on factors of the quality of web service. Phys. Proc, 2012, 33: 1992-1998.

[38] Xie Y, Mao Z. Evaluation of residential energy-saving buildings based on grey relational analysis method. Proc. Eng, 2012; 29: 3149-3153.

[39] Song L, Yue Y L, Di F K, Wei Q P, Gao Z Q, Zhang J X. Effects of alternative partial root zone irrigation on peach growth, productivity, and water use efficiency. China. J. Appl. Ecol, 2008; 19(7): 1631-1636. (in Chinese)

[40] Jovanovic Z, Stikic R, Vucelic-Radovic B, Paukovica M, Brocica Z, Matovica G, et al. Partial root-zone drying increases WUE, $\mathrm{N}$ and antioxidant content in field potatoes. Eur. J. Agron, 2010; 33(2): 124-131.

[41] Nong M L, Wei G Y, Li F S. Effect of partial root-zone irrigation at different growth stages on dry mass accumulation and water and nitrogen use of maize. J Maize Sci, 2012; 20: 115-120.

[42] Wang C H, Zhu P F, Shu L Z, Zhu J R, Yu H M, Zhan Y S, 
et al. Effects of alternate partial root-zone irrigation and nitrogen forms on utilization and movement of nitrate in soil. Trans. Chin. Soc. Agric. Eng, 2014; 30(11): 92-101. (in Chinese)

[43] Du T, Kang S Z, Zhang J H, Davies W J. Deficit irrigation and sustainable water-resource strategies in agriculture for China's food security. J. Exp. Bot, 2015; 66(8): 2253-2269.

[44] Kirda C, Baytorun N, Derici M R, Dasgan H Y. Nitrogen fertilizer recovery and yield response of greenhouse grown and fertigated tomato to root-zone soil water tension. Turk. J. Agric. Forest, 2003; 27: 323-328.

[45] Xing Y Y, Zhang F C, Wu L F, Fan J L, Zhang Y, Li J. Determination of optimal amount of irrigation and fertilizer under, drip fertigated system based on tomato yield, quality, water and, fertilizer use efficiency. Trans. Chin. Soc. Agric. Eng, 2015; 31: 110-121. (in Chinese)

[46] Hu X T, Kang S Z, Zhang J H, Zhang F C, Li Z J, Zhou L C. Water-saving mechanism and efficiency of vertical partial-root zone alternative controlled drip irrigation of tomato. Trans. Chin. Soc. Agric. Eng, 2005; 7: 1-5. (in
Chinese)

[47] Du T S, Kang S Z, Zhang J H. Response of cotton growth and water use to different partial root zone irrigation. Sci. Agric. Sin, 2007; 40(11): 2546-2555. (in Chinese)

[48] Song $\mathrm{H} \mathrm{X}$, Li S X. Changes of root physiological characteristics resulting from supply of water, nitrogen supply and root-growing space in soil. Plant Nutr. Fert. Sci, 2004; 10(1): 6-11. (in Chinese)

[49] Qiu X Y, Wang C Y, Wang Y L, Zhu Y J, Guo T C. Effects of nitrogen application rate on root system distribution and grain yield of winter wheat cultivars. Acta Agric. Boreali-occidentalis Sinica, 2012; 21(1): 53-58. (in Chinese)

[50] Liu S Q, Cao H X, Zhang J Q, Hu X T. Effects of different water and nitrogen supplies on root growth, yield and water and nitrogen use efficiency of small pumpkin. Sci. Agric. Sin, 2014; 47(7): 1362-1371. (in Chinese)

[51] Qi H Y, Li T L, Zhang J, Wang L, Chen Y H. Effects on sucrose metabolism, dry matter distribution and fruit quality of tomato under water deficit. J. Integr. Agric, 2003; 11: 1253-1258. 